\title{
NATIVE AND NON-NATIVE PLANTS ATTRACT DIVERSE BEES TO URBAN GARDENS IN CALIFORNIA
}

\author{
Gordon Frankie ${ }^{1}$, Jaime Pawelek ${ }^{2}$, Marissa H. Chase ${ }^{1}$, Christopher C. Jadallah ${ }^{1}$, Ingrid Feng ${ }^{1}$, Mark \\ Rizzardi³, Robbin Thorp ${ }^{4}$ \\ ${ }^{1}$ University of California, Berkeley; Department of Environmental Science, Policy, and Management. 94720 \\ ${ }^{2}$ University of California, Berkeley, College of Natural Resources, 94720 \\ ${ }^{3}$ Humboldt State University, Department of Mathematics and Statistics, Arcata, California 95521 \\ ${ }^{4}$ University of California, Department of Entomology, Davis, California 95616
}

\begin{abstract}
Bees visit native and non-native plant species for pollen and nectar resources in urban, agricultural, and wildland environments. Results of an extensive survey of bee-flower collection records from I0 California cities from 2005-20I I were used to examine host-plant records of native and non-native ornamental plants to diverse native and non-native bee species; five cities were from northern California and five were from southern California. A total of 7,659 bees and their floral host plants were examined. Of these, I79 were Apis mellifera and 7,390 were non-Apis. Only four other non-native species (all in Megachilidae) were recorded in the survey, and together they accounted for 402 individuals. These bees have been databased in preparation for deposition in the University of California-Berkeley Essig Museum of Entomology. We identified 229 bee species and 42 genera visiting native and non-native plant types in urban areas. Of the 229 species, 7I bee species were collected from only native plants; 52 were collected from only non-native host plants; and 106 were collected from both types of plants. Native bee species were common on native plants and non-native plants, but there were substantially more non-native bee species visiting non-native plants compared to native plants. Flowering periods in months were similar for both types of plants, but non-natives tended to flower later in the year. We propose that using native and non-native plants improves habitat gardening by increasing opportunities for attracting a richer diversity of bee species and for longer periods. Knowing basic bee-flower relationships in an area is key to planning a bee habitat garden with a variety of plant types, regardless of their geographic origin.
\end{abstract}

Keywords: $\quad$ habitat gardens, urban bees, native plants, native pollinators, native bees, Apis mellifera

\section{INTRODUCTION}

The importance of native pollinators, and especially bees, has generated increased attention in recent years in the scientific and popular press, propelled by recognition of their ecological importance, aesthetic value, and ecosystem services they provide (Owen I991; Buchmann \& Nabhan I996; Losey \& Vaughan 2006; NAS 2007; Tepedino et al. 2008; Winfree 20I0; Mader et al. 20II; Garibaldi et al. 20I3; O'Toole 20I3; Williams et al. 20I4; Atkins \& Atkins 20I6; Wilson \& Carrill 2016; Hall et al. 2017; Embry 2018; Hanson 2018).

This interest is coupled with an awareness that pollinators are declining globally (Buchmann \& Nabhan 1996; Cane \& Tepedino 200I; Potts et al. 20I0; Williams et al. 20I4; Baldock et al. 20I5; Atkins \& Atkins 2016; Koh et al. 2016;). These trends have also prompted conservation efforts for bee pollinators in agricultural and urban environments (NAS 2007; Hernandez et al. 2009; Mader et al. 20I I; Frankie et

Received 3 July 2018, accepted 30 January 2019

${ }^{*}$ Corresponding author: gwfrankie@berkeley.edu al. 20I4, 20I8; Kleijn et al. 20I4; Baldock et al. 20I5; Harrison et al. 2017).

With regard to urban areas, which are increasing worldwide, there has been a proliferation of papers recently on bee species richness and abundance in cities (Frankie et al. 2005, 2009a, 2013, 2014; Nates-Parra et al. 2006; Nemesio and Silveira 2007; Matteson et al. 2008; Pawelek et al. 2009; Tallamay 2009; Pardee \& Philpott 20I4; Baldock et al. 20I5). Survey work has provided much evidence that urban areas can offer suitable habitat for reproduction and survival of many bee species. Frankie et al. (pg. xiv 2014 and unpublished.) opportunistically sampled $50+$ urban sites for more than 15 years throughout California, and determined there were more than 400 bee species, which represents $25 \%$ of the known 1,600 bee species recorded from the state Surveys in single small gardens also reveal relatively high species richness. Long-term monitoring in one small residential garden in Leicester, England yielded 5I bee species, which represents $20 \%$ of Britain's 256 native bee species (Owen I99I). Frankie et al. (2013) surveyed bees visiting 62 native and 40 non-native ornamental and weed plant species in two cities in NW Costa Rica over a IO-yr period and recorded 125 bee species, which represents about $18 \%$ of the $700+$ bee species in the country. See other relevant studies by Jaime et al. (2009); Frankie et al. (2009b). Some papers have 
suggested ways to enhance bee activity, for example, through urban pollinator habitat gardens, hedgerows and other ways (NAS 2007; Pawelek et al. 2009; Mader et al. 20I I; Frankie et al. 20I4; Tallamay 2009).

In our California experience, one common question that emerges from urban audiences is, should native and non-native host plants be used to encourage bee species activity in gardens or similar types of plantings? There is growing interest and some debate on this question (Pardee \& Philpott 20I4; Salisbury et al. 2015; Frankie et al. 2018). See also Tepedino et al. 2008 and Williams et al. 201 I for different, but relevant views. In this paper, we offer a perspective on this question based on years of work conducted throughout California and other states. It seems clear that it is not always a simple question with a simple answer. Our perspective is based on extensive collection records and observational work on beeflower relationships conducted in the state over 20 years of urban (and agricultural) field work.

\section{Goals}

Our goal was to examine past bee-flower records collected in urban California to evaluate the relative attractiveness of native versus non-native plants to bees in bee habitat gardens and other habitats with flowers. Using extensive survey data of bee-flower relationships gathered throughout northern and southern California gardens from 2005-20I I (Frankie et al. 2009a, 20I4), we compared the most attractive native and non-native plants with native and non-native bees to make assessments by:
I. Comparing total number of native and non-native bee species and genera with native and non-native plants.

2. Comparing blooming periods of native and non-native plants.

\section{MATERIALS AND METHODS}

\section{Site Descriptions}

Bee-flower collection records from I0 California cities (Fig. I and see map on page xv in Frankie et al. 20I4) were used to examine attraction patterns. Northern California cities were Redding, Ukiah, Sacramento, Santa Cruz, and Berkeley; southern cities were San Luis Obispo, Santa Barbara, Riverside, La Canada Flintridge (near Pasadena), and Palm Springs (Palm Desert). Sampling was conducted in diverse sites, which included botanic gardens, arboreta, community gardens, private home gardens, cemetery gardens, fallowed lots, and city/ county space within these cities.

\section{Collections and observations}

Collections and extensive observations were made by experienced bee collectors from the Urban Bee Lab at the University of California, Berkeley. Collecting was done when climatic conditions were favorable and collectors were available. Most sampling occurred during spring and summer months (March through August).

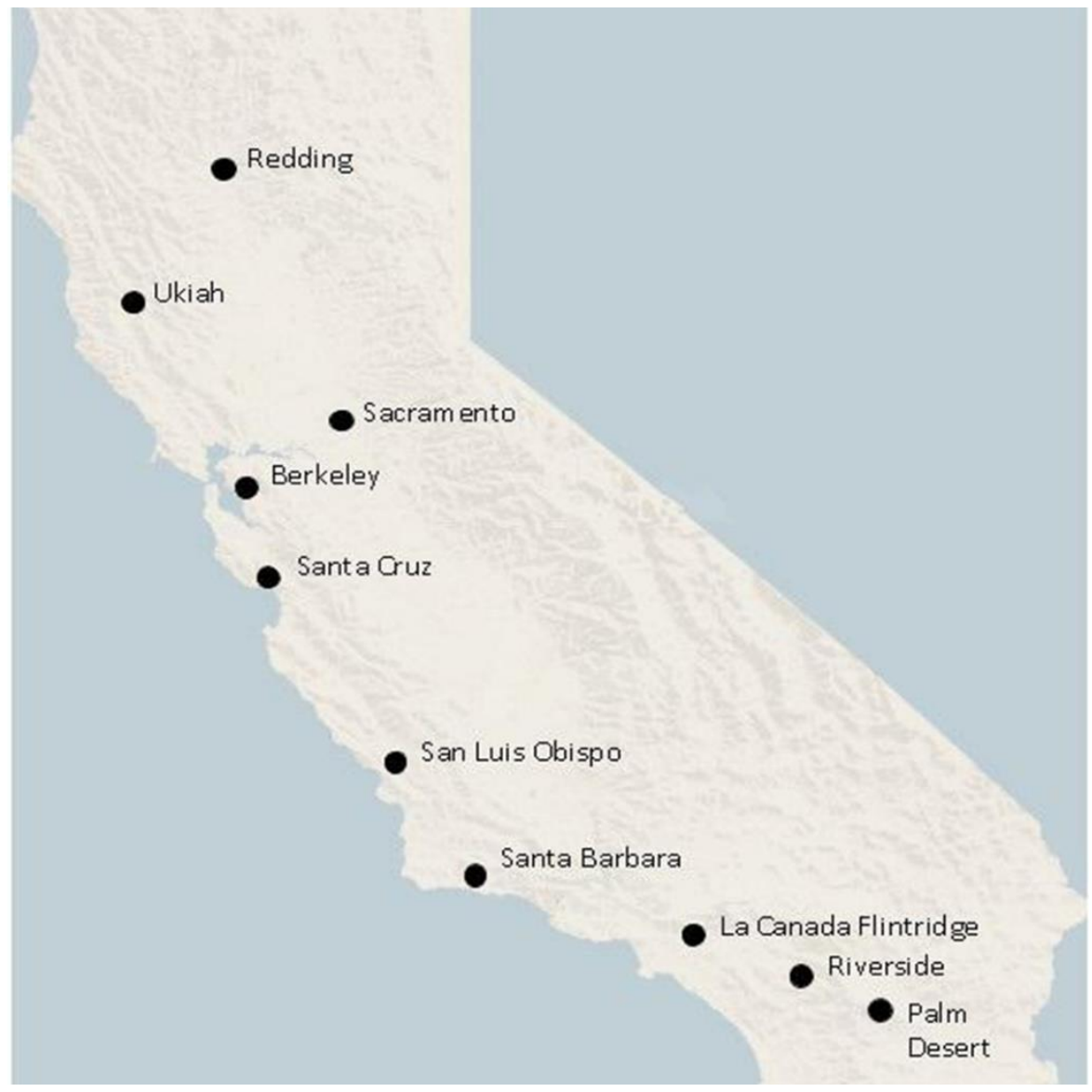

Figure I: Map of Surveyed California Cities (figure is modified from map on Page xv of California Bees \& Blooms (Frankie et. al., 2014)) 
Bees were collected directly from flowers using aerial nets. To standardize a visit, only bees that made contact with reproductive parts of flowers were collected. Collectors sampled opportunistically for 2-4 hours from mid-morning to mid-afternoon on days of at least I8 degrees C. Representative specimens of one or two bee species from each plant were collected and kept separate.

Bees were pinned and labeled at the Urban Bee Lab. J. Pawelek and R. Thorp identified the bees to species, which were then databased using Microsoft Access. The databased bees have been prepared for eventual deposition in the UC Berkeley Essig Museum of Entomology. A total of 7,569 bees were collected during the study. Of these, 179 were Apis mellifera and 7,390 were non-Apis. Only four non-native bee species other than $A$. mellifera were recorded in the survey: Megachile rotundata ( $N=2 \mathrm{II}$ individuals), $M$. apicallis ( $N$ $=82)$, $M$. concinna $(N=28)$, and Anthidium manicatum $(N$ $=8 \mathrm{I})$.
We use the term "plant types" to represent well recognized plant species and others that represent cultivars, which were common in urban environments. After entries were made, the database was separated to include only plant types that were found in at least five of the $\mathrm{IO}$ cities so as to focus on the more common species and cultivars. This narrowed our plant list from over IIO native and II5 nonnative plant types to I5 natives and 19 non-natives. See Fig. 2 for origins of non-natives included in the study.

Of the 34 total plant types, 26 were easily identified to species level during collection events. The remaining eight types were determined only to genus as the large variety of species and cultivars within these genera are difficult to distinguish (e.g. natives: Ceanothus spp. + cvs. and Erigeron glaucus + cvs.; non-natives: Gaillardia spp. + cvs. and Lavandula spp. + cvs.). Lists of all bee collected from these I 5 natives and 19 non-natives were then compiled for analysis.
Europe/Mediterranean

Calendula sp.

Echium candicans

Lavandula spp. + cvs.

Linaria purpurea

Rosmarinus officinalis + cvs.

Vitex agnus-castus

Africa

Lavandula spp. + cvs.

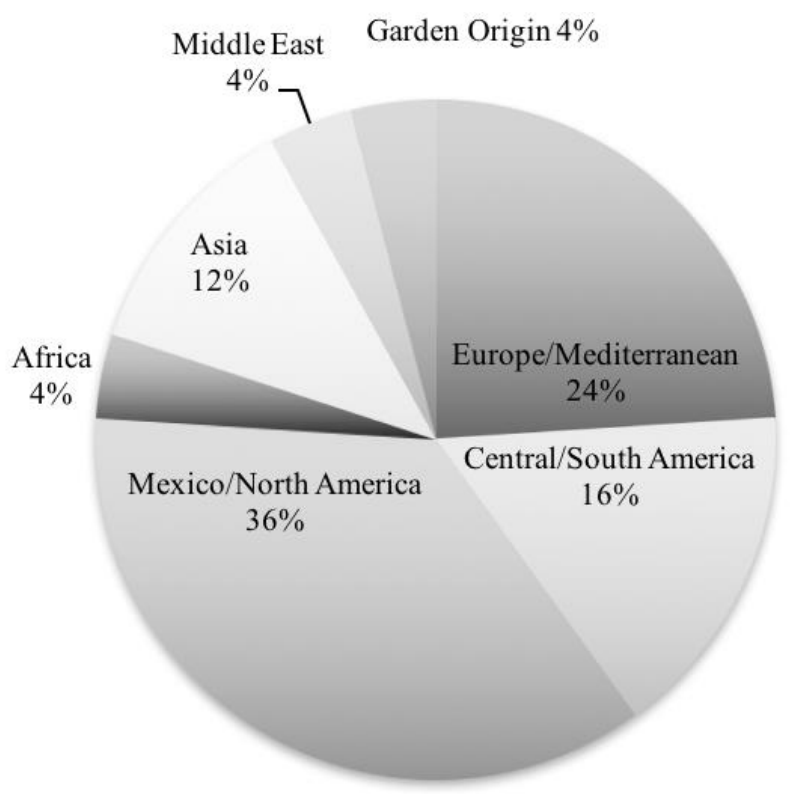

Central/South America

Bidens aurea

Erigeron karvinskianus

Gaillardia spp. + cvs.

Salvia uliginosa

Mexico/North America

Bidens aurea

Coreopsis spp. + cvs.

Cosmos bipinnatus

Cosmos sulphureus

Erigeron karvinskianus

Gaillardia spp. + cvs.

Penstemon spp. + cvs.

Rudbeckia hirta + cvs.

Salvia chamaedryoides

Asia

Middle East

Lavandula spp. + cvs.

Penstemon spp. + cvs.

Perovskia atriplicifolia
Nepetaspp. + cvs.

\author{
- Garden Origin (hybrids) \\ Aster $x$ frikartii
}

FIGURE 2: Origins of non-native plants surveyed in this study 
TABLE I: Number of native and non-native (in parentheses) bee species visiting native and non-native plant types in survey.

\begin{tabular}{|c|c|c|c|c|}
\hline & $\begin{array}{c}\text { Visit Native Plants } \\
\text { Only }\end{array}$ & $\begin{array}{l}\text { Visit Non-native Plants } \\
\text { Only }\end{array}$ & $\begin{array}{l}\text { Visit Native and Non- } \\
\text { Native Plants }\end{array}$ & Totals \\
\hline Number of Bee Species & $7 \mathrm{I}(0)$ & $52(0)$ & $\mathrm{IOI}(5)$ & 229 \\
\hline Number of Bee Genera & $6(0)$ & $3(0)$ & $32(\mathrm{I})$ & 42 \\
\hline
\end{tabular}

TABLE 2: Native and non-native bee species and genera recorded from native plants. Number in parentheses represents consistent bee taxa for which there were three specimens recorded from the plant type in at least two different years.

\begin{tabular}{|c|c|c|c|}
\hline Native Plant Type & Total Native Bee Species & $\begin{array}{c}\text { Total Non-Native Bee } \\
\text { Species }\end{array}$ & Total Bee Genera \\
\hline Achillea millefolium L. & $18(4)$ & $\mathrm{I}(0)$ & $10(2)$ \\
\hline Arctostaphylos spp. + cvs. $^{\mathrm{I}}$ & $16(5)$ & $0(0)$ & $8(3)$ \\
\hline Berberis nevinii & $10(3)$ & $0(0)$ & $6(3)$ \\
\hline Ceanothus spp. + cvs. $^{2}$ & $5 \mathrm{I}(20)$ & $0(0)$ & $\mathrm{I} 2(7)$ \\
\hline Encelia californica Nutt. & $30(8)$ & $0(0)$ & $16(6)$ \\
\hline Erigeron glaucus + cvs. $^{3}$ & $34(9)$ & $2(\mathrm{I})$ & I8 (8) \\
\hline Eriogonum fasciculatum Benth & $22(7)$ & $\mathrm{I}(0)$ & $\mathrm{I} 2(5)$ \\
\hline Eschscholzia californica Cham. & $42(\mathrm{I} 7)$ & $0(0)$ & I5 (7) \\
\hline Grindelia hirsutula Hook \& Arn & $16(5)$ & $\mathrm{I}(0)$ & $\mathrm{I} 2(4)$ \\
\hline Helianthus annuus L. & I5 (7) & $0(0)$ & $\mathrm{IO}(4)$ \\
\hline Phacelia tanacetifolia Benth & $54(\mathrm{I} 6)$ & $3(0)$ & $20(12)$ \\
\hline Salvia clevelandii (A. Gray) Greene & $8(2)$ & $0(0)$ & $6(2)$ \\
\hline Salvia leucophylla Greene & $19(3)$ & $0(0)$ & II (2)) \\
\hline Salvia mellifera Greene & $32(7)$ & $\mathrm{I}(\mathrm{I})$ & $\mathrm{I} 5(5)$ \\
\hline Solidago californica Nutt & $34(\mathrm{II})$ & $2(\mathrm{I})$ & $18(5)$ \\
\hline
\end{tabular}

I. Arctostaphylos densiflora M.S. Baker, Arctostaphylos hookeri G. Don, Arctostaphylos 'Dr. Hurd', Arctostaphylos pumila Nutt., Arctostaphylos sp. 2. Ceanothus thyrsiflorus 'Skylark', Ceanothus thyrsiflorus Eshsch., Ceanothus Julia Phelps', Ceanothus 'Marie Sim.', Ceanothus 'Cal Poly', Ceanothus 'Ray Hartman', Ceanothus 'Snow Flurry', Ceanothus 'Sierra Blue', Ceanothus 'Mountain Haze', Ceanothus 'Wheeler Canyon', Ceanothus 'Frosty Blue', Ceanothus Dark Star', Ceanothus 'thyrsiflorus 'Serra Snow', Ceanothus hearstiorum Hoover \& J.B. Roof, Ceanothus gloriosus J.T. Howell, Ceanothus griseus (Trel.) McMinn, Ceanothus maritimus Hoover., Ceanothus oliganthus Nutt, Ceanothus 'Gentian plume', Ceanothus Bee's Bliss', Ceanothus sp.

3. Erigeron glaucus Ker Gawl., Erigeron glaucus Wayne Roderick', Erigeron glaucus 'Bountiful'

\section{RESULTS}

We identified 229 bee species and 42 genera visiting our selection of 15 native and 19 non-native plant types in urban areas (Table I and Appendix I). Of the 229 species, 7I were from only native host plants; 52 were from only non-native host plants; and 106 were from both native and non-native hosts. Five of the 106 were non-native bee species. Of the 42 genera, six were from only native plants; three were from only non-native hosts; and 33 were from both native and nonnative host flowers. Only one non-native bee species was recorded for both native and non-native hosts (Table I). Cleptoparasitic bees were treated as potential pollinators as many or most individuals carry small amounts of pollen on their bodies and thereby have the potential to pollinate at low levels.

The six bee genera found visiting only native plants were Calliopsis, Chelostoma, Conanthalictus, Melecta, Panurginus, and Perdita. Calliopsis sp. and Perdita sp. were only found visiting the native Eschscholzia californica. Chelostoma sp. and Conanthalictus sp. were found visiting only the native Phacelia tanacetifolia. Melecta sp. was found visiting only the native Salvia mellifera. Panurginus spp. was found visiting the natives Ceanothus spp. + cvs. and Phacelia tanacetifolia. The three genera found only visiting non-native plants were Anthophorula, Dolichostelis and Epeolus. Anthophorula sp. was collected only from Penstemon spp. + cvs, Dolichostelis sp. was collected only from Rosmarinus officinalis, and Epeolus sp. was collected only from Erigeron karvinskianus.

Table 2 lists native plant types from which native and non-native bee species were collected. Native bee species were common, as expected, on native plants. Only seven of the I5 native plant types (47\%) attracted a few non-native bees, with a low number of consistent species. Only three of the seven non-natives were recorded in this group. 
Table 3 lists non-native plant types from which native and non-native bee species were collected. As with the native plants, native bee species were common on non-native plants. In contrast to native plants in Table 2 , there were substantially more non-native bee species visiting non-native plants compared to native plants (Table 2). Sixteen of the 19 nonnative plants (84\%) attracted non-native bee species, and nine of the 16 had consistent visitors.

A plant type's status as native or non-native did not indicate how many bee species it can attract. For example, the native Phacelia tanacetifolia, Ceanothus spp. $+\mathrm{cvs}$, and Eschscholzia californica attracted 57, 5I, and 4I bee species respectively. The non-native Lavandula spp. + cvs., Nepeta spp + cvs., and Aster x frikartii attracted 53, 52, and 43 bee species respectively (Tables $2 \& 3$ ).

Native and non-native plant types often attracted different bee taxa. Based on years of extensive bee visitation or frequency counts in California, most urban bee plants attracted certain predictable taxonomic groups and rarely others (Frankie et al., 2009a, 20I4; see also Frankie et al. 2013 for similar findings in Costa Rica). There were some variations with this generalization, but hundreds of counts made over multiple years support this generalization.
Comparing the non-native Salvia chamaedryoides and the native Salvia clevelandii illustrated this phenomenon (Table 4). Salvia chamaedryoides attracted 8 bee species, and $S$. clevelandii also attracted 8 bee species. Together, they attracted 12 bee species. Planting $S$. chamaedryoides with $S$. clevelandii could invite an additional four bee species that do not visit $S$. clevelandii into a garden, thus increasing overall pollinator diversity.

Comparing blooming activity of 19 non-native with that of I5 native plant types illustrate similarities. Ranges of flowering periods were 3-8 months and 3-12 months, respectively, for natives versus non-natives (3-8 months for both if the 12 months of Erigeron karvinskianus is excluded). Average flowering periods were also similar, 4.8 +/- SD 1.52 months for natives and 5.I +/- SD 2.12 months for nonnatives. Non-native plants bloom later and longer in the year than native plants (Figs. 3 and 4). The ratio of non-native to native plants in flower increased as the year progresses. In February, only $16.7 \%$ of the plants in flower were non-native. In June, $61 \%$ were non-native, and in October, $86 \%$ of the flowering plants were non-native with only I $4 \%$ of flowering plants being native.

TABLE 3: Native and non-native bee species and genera recorded from non-native plants. Number in parentheses represents "consistent" bee taxa for which there were at least three specimens recorded in at least two different years.

\begin{tabular}{|c|c|c|c|}
\hline Non-Native Plant Type & Total Native Bee Species & Total Non-Native & Total Bee Genera \\
\hline Aster $x$ frikartii & $40(\mathrm{I} 7)$ & $3(3)$ & $22(\mathrm{II})$ \\
\hline Bidens aurea (Aiton) Sherff & $22(8)$ & $2(2)$ & I5 (7) \\
\hline Calendula sp. & $16(4)$ & $2(0)$ & $8(2)$ \\
\hline Coreopsis spp. + cvs. ${ }^{1}$ & $33(12)$ & $2(2)$ & $16(7)$ \\
\hline Cosmos bipinnatus Cav. & $3 \mathrm{I}(8)$ & $\mathrm{I}(0)$ & $13(6)$ \\
\hline Cosmos sulphureus Cav. & $9(2)$ & $\mathrm{I}(0)$ & $7(2)$ \\
\hline Echium candicans L.f. & $\mathrm{I} 8(5)$ & $0(0)$ & $\mathrm{I} 2(4)$ \\
\hline Erigeron karvinskianus Dc. & $29(4)$ & $2(2)$ & $\mathrm{I} 7(5)$ \\
\hline Gaillardia spp. + cvs. $^{2}$ & $26(8)$ & $0(0)$ & $\mathrm{I} 4(6)$ \\
\hline Lavandula spp. + cvs. $^{3}$ & $5 \mathrm{I}(29)$ & $2(0)$ & $2 \mathrm{I}(\mathrm{I} 3)$ \\
\hline Linaria purpurea (L.) Mill. & $20(4)$ & $2(2)$ & II (4) \\
\hline Nepeta spp. + cvs. ${ }^{4}$ & $49(23)$ & $3(2)$ & $2 \mathrm{I}(\mathrm{I} 3)$ \\
\hline Penstemon spp. + cvs. ${ }^{5,6}$ & $34(9)$ & $0(0)$ & $15(7)$ \\
\hline Perovskia atriplicifolia Benth. & $26(13)$ & $2(\mathrm{I})$ & $16(9)$ \\
\hline Rosmarinus officinalis + cvs. ${ }^{7}$ & $27(9)$ & $2(\mathrm{I})$ & $19(7)$ \\
\hline Rudbeckia hirta + cvs. ${ }^{8}$ & $22(5)$ & $\mathrm{I}(0)$ & $16(5)$ \\
\hline Salvia chamaedryoides & $9(2)$ & $\mathrm{I}(0)$ & $7(2)$ \\
\hline Salvia uliginosa & $28(9)$ & $\mathrm{I}(0)$ & I5 (8) \\
\hline Vitex agnus-castus $\mathrm{L}$. & $37(\mathrm{I} 7)$ & $2(\mathrm{I})$ & I6 (II) \\
\hline
\end{tabular}

I. Coreopsis verticillata L., Coreopsis grandiflora Hogg, ex Sweet, Coreopsis sp., Coreopsis 'Sunray', Coreopsis 'Domin', Coreopsis tinctoria Nutt, Coreopsis Nana', Coreopsis 'Sunny Day', Coreopsis Flying Saucers', Coreopsis lanceolata L., Coreopsis auriculata L.

2. Gaillardia sp., Gaillardia aristata Pursh, Gaillardia x grandiflora, Gaillardia x grandiflora 'Oranges \& Lemons',

3. Lavandula sp., Lavandula heterophylla, Lavandula Provence', Lavandula dentata. var. Candicans L.; Lavandula stoechas L., Lavandula 'Helmsdale'

4. Nepeta sp., Nepeta tuberosa, Nepeta x faassenii, Nepeta 'Six Hills Giant', Nepeta grandiflora M. Bieb,

5. Penstemon sp., Penstemon 'Midnight,'Penstemon parryi(A. Gray) A. Gray

6. This list excludes the Penstemon spp. that are native to California.

7. Rosmarinus officinalis L., Rosmarinus officinalis 'Lockwood de Forest'

8. Rudbeckia hirta L., Rudbeckia hirta 'Indian Summer' 
TABLE 4: Native bee species recorded from non-native Salvia chamaedyroides and native Salvia clevelandii in study survey

\begin{tabular}{lll}
\hline Salvia chamaedryoides (non-native) & Salvia clevelandii (native) & Both Salvia chamaedryoides and Salvia clevelandii \\
\hline Anthidium maculosum & Agapostemon texanus & Halictus tripartitus \\
Anthophora californica & Andrena candida & Melissodes tepida timberlakei \\
Anthophora urbana & Bombus melanopygus & Xylocopa tabaniformis orpifex \\
Melissodes communis alopex & Xylocopa varipuncta & Bombus californicus \\
\hline
\end{tabular}

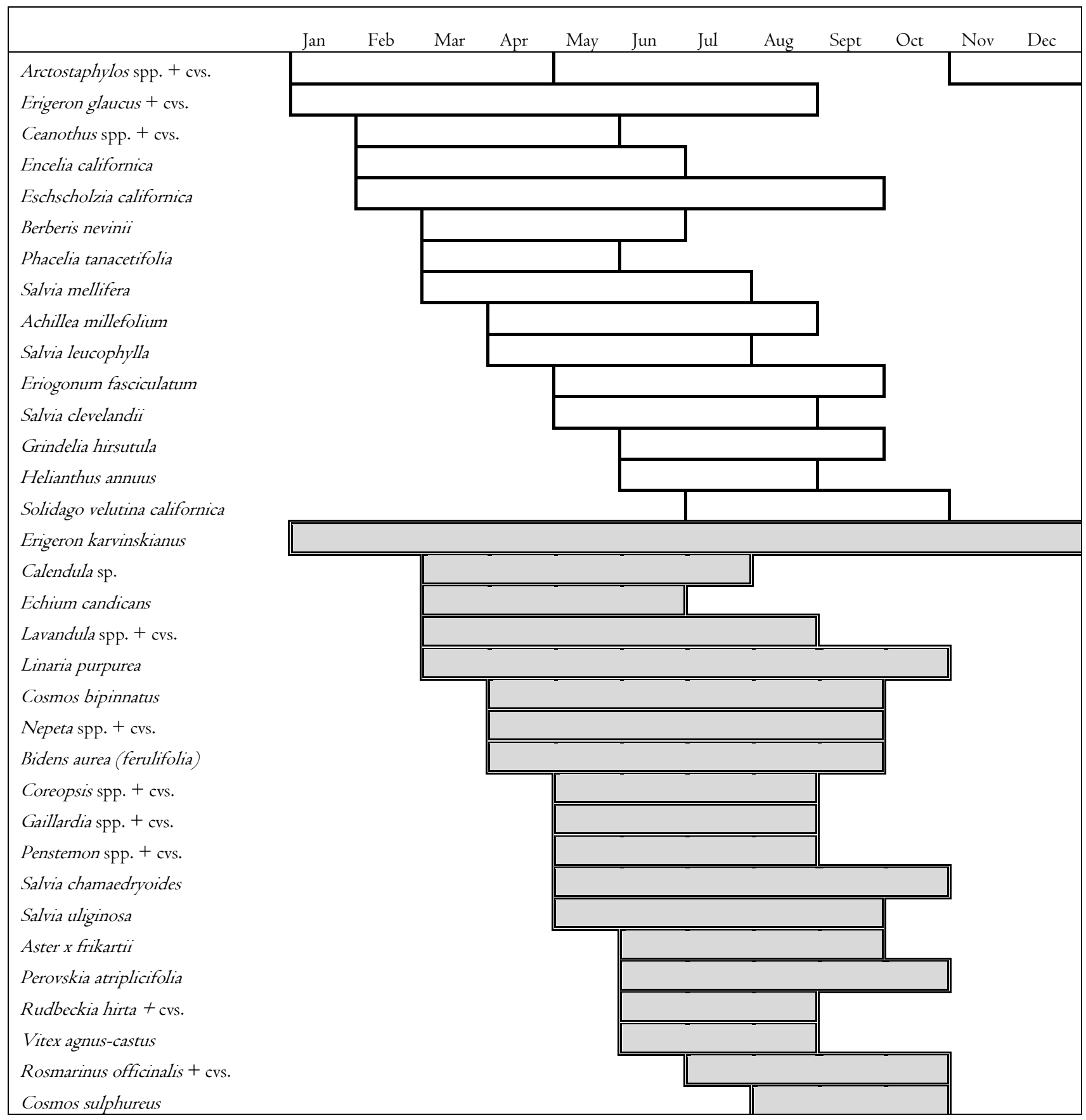

FIGURE 3. Blooming periods of native and non-native plant species in study survey. Open bars represent native plants and gray represent nonnative plants 


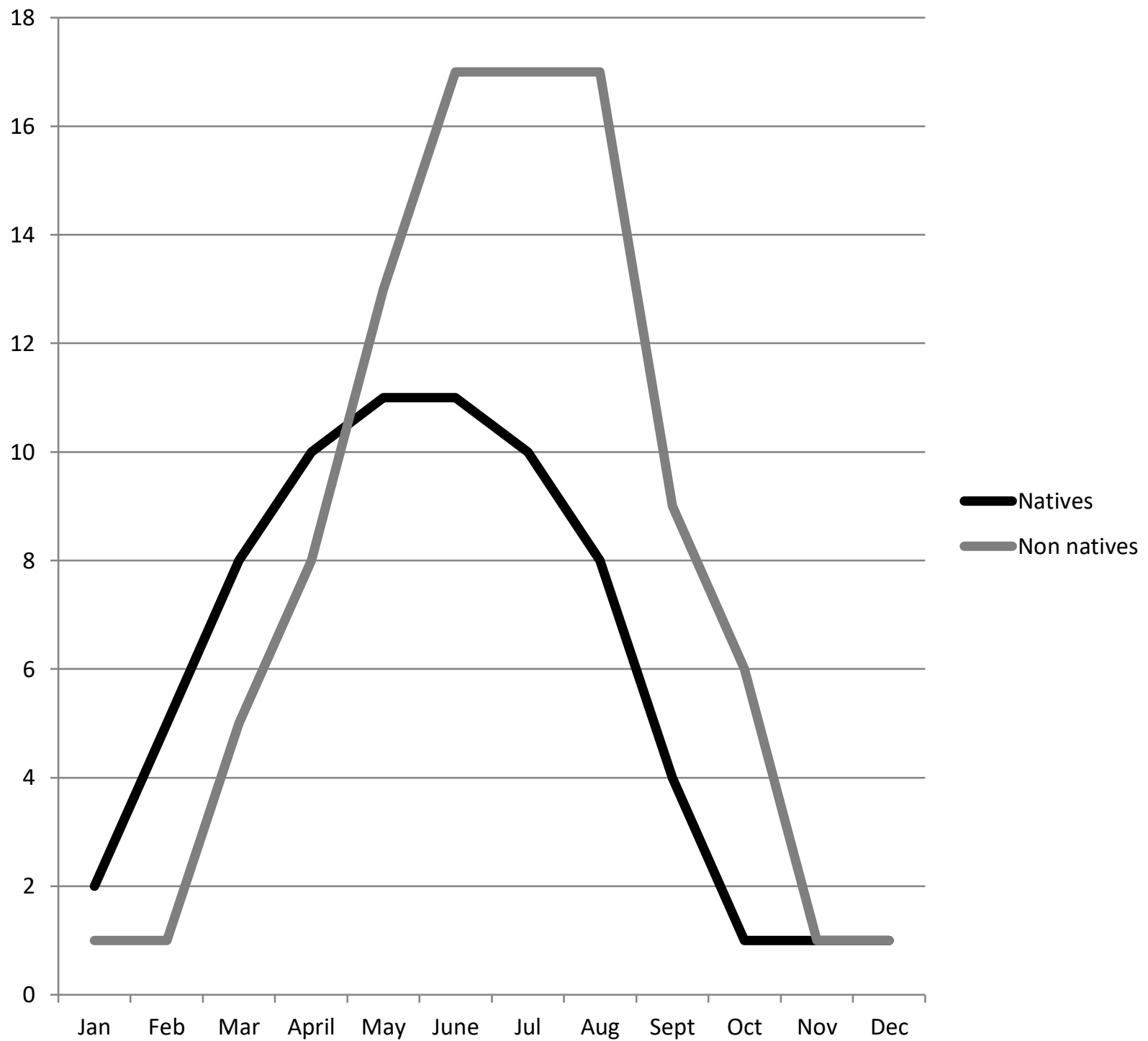

FIGURE 4. Number of I5 native and I9 non-native species in bloom throughout year (see Table 2 and 3)

Examining flowering phenologies of $S$. chamaedryoides and $S$. clevelandii one observes overlap between a plant's bloom time and flight activity period of bees that visit the plants (Tables 2, 3, \& 5). Non-native $S$. chamaedryoides flowered from May until October, whereas native $S$. clevelandii bloomed earlier in the season from March until August. Salvia chamaedryoides bloomed for an additional two months more than $S$. clevelandi, and this was associated with the flight seasons of bees that are attracted to this non-native plant. Including $S$. chamaedryoides in a garden may introduce new species like Anthidium maculosum, A. manicatum, and Anthophora urbana that rely on floral resources provided by plants that bloom through October, as these bees' flight periods extend into the fall months.

\section{DISCUSSION}

Our survey research indicates that incorporating both native and non-native ornamental plants into habitat gardens may be beneficial by providing more diverse habitat for bees in urban areas. This supports the larger concept that non- native species can provide conservation benefits by providing food and habitat for native species as well as providing desirable ecosystem functions (Schlaepfer et al. 20II). A prevailing attitude amongst many urban gardeners with whom we work is that native plant gardening is a "best practice" for habitat gardening, leading many to work exclusively with natives. There are, of course, many benefits to native plant gardening as native plants are often well-adapted to local climates and provide food and shelter to wildlife (Tallamay 2009). Gardening with select non-native plants, however, can supplement floral resources to support more diverse bee populations. Bees require flowers for both nectar and pollen, and many bee species are generalists in their choice of plants. Incorporating native and non-native plant types into a bee garden can increase the total number of bee species found there.

Of the 229 bee species found visiting the 34 plant types in this study, 52 bee species were recorded only from nonnative plants (Table I). Plants having the most consistent bee species visiting them were Lavandula spp. + cvs with 29 bee 
TABle 5: $\quad$ Flight Periods of Native Bee Species Visiting S. chamaedryoides and S. clevelandii

\begin{tabular}{ll}
\hline $\begin{array}{l}\text { Flight Season of Native Bees Visiting Salvia } \\
\text { chamaedryoides (nonnative) }\end{array}$ & $\begin{array}{l}\text { Flight Season of Native Bees Visiting Salvia clevelandii } \\
\text { (native) }\end{array}$ \\
\hline Anthidium maculosum: June - Oct & Agapostemon texanus: March - Oct \\
Anthophora californica: March - July & Andrena candida: Feb - June \\
Anthophora urbana: April - October & Bombus melanopygus: Jan - Aug \\
Melissodes communis alopex: June - Aug & Xylocopa varipuncta: March - Sept. \\
\hline
\end{tabular}

species visitors, Nepeta spp. + cvs with 25 bee species visitors, Aster x frikartii with 20 bee species visitors, and Ceanothus spp. + cvs also with 20 bee species visitors (Table 3 ). These first 3 plants are all non-native, followed by the native Ceanothus spp. + cvs (Table 2).

Tepedino et al. (2008) assessed which bee species were visiting I0 selected plant taxa (7 native, 3 invasive) in Capitol Reef National Park, Utah and reached similar conclusions. They found that non-native plant species had as many or more native bee species and individuals as did native plant species, and thus played an important role in increasing the Park's native bee carrying capacity. Their study focused on a wildland habitat and weedy plants, whereas the current study focused on urban habitats and installed ornamental plants. Both have important conservation implications regarding the design of pollinator habitats.

Beyond increasing overall species abundance, another reason for incorporating non-native plants into a bee garden is that they may extend a garden's flowering time, thus providing more resources for bees later in the year and possibly attracting new bee species. Many non-alpine California native plants typically bloom earlier in the year as a result of the region's Mediterranean climate, in which wet winters encourage flowering in the spring and early summer months before the dry summer sets in. Of the plants highlighted in this study, there are more non-native taxa in bloom later in the season (summer/fall) compared to earlier in the season (winter/spring) (see Figs. 3 and 4). A study conducted in the UK recorded a similar pattern: non-native plants extended the flowering season (Salisbury 2015). Tepedino et al. (2008) noted that non-native plants have actually increased wildland native bee carrying capacity in Capitol Reef National Park potentially because they filled in a mid-summer gap in floral resources. Although percentages calculated from our study ( $16.7 \%$ of the plants in flower in February are non-native, and $86 \%$ are non-native in October) would only be valid of a garden made up of our highlighted 34 plant types. A study conducted in Poznan, Poland by Banaszak-Cibicka \& Zmihorski (20II) demonstrated that presence of a bee species in an urban area depends on the species' flight season and phenologies of the area's floral resources. This study found that the recorded low numbers of early spring bees in the urban area was "likely due to a lack of appropriate floral resources during flight times of these bees."

Providing floral resources for the entire duration of the bee season (mid-December through October) in California is an important factor to consider when planning a bee habitat garden. Many bee species only have a single generation per year and, are active as adults for only a short period (e.g. Melissodes robustior). Other species are multi-generational, having a longer flight season as adults, as they will emerge from their nest cavities at multiple points throughout the year (e.g. Agapostemon texanus). Some species are social and also have a long flight season as their colonies are active throughout the year (e.g. Bombus vosnesenskii). Plants that flower later in the season are important resources for not only singlegeneration bees that are active in either the summer and fall, but multi-generation bees and social bees, too, such as honey bees.

Supporting diverse bee populations via habitat gardening can be an important tool in larger conservation work involving native bees. Urban areas can act as refuges for bee diversity (Hall et al. 2016). California's I,600 native bee species have coevolved with California's 6,000+ flowering plant species, forming a relationship that is integral to ecosystem health and the state's natural resource heritage. Furthermore, urban landscape gardens can be ideal sites for long-term pollinator monitoring because they are usually intensively managed, and usually provide more consistent floral resources than wild landscapes where floral resource availability may be limited by factors such as drought, and even fire. Urban areas can even serve as genetic reserves for pollinators and other species that are beneficial for humans, some of them undoubtedly being a resource for the pollination of agricultural crops (Owen I99I; Frankie et al. in press). Bees in urban environments can also be subjects of environmental education, offer aesthetic pleasure, and pollinate garden plants (both edible and nonedible) (Mader et al. 20I I; Frankie et al. 20I4; Embry 20I8; Hanson 2018).

We have presented evidence from our years of field collections and observations on bees and their host flowers that native and non-native plants, when grown together, in a garden can support native bees. The key is knowing basic relationships between bees and their preferred plants in an area, and then acting accordingly on these relationships to construct gardens to support them. When we construct bee habitat gardens in urban and agricultural areas, our focus is on plants that bees prefer for pollen and nectar and not on whether the plants are native or non-native. This knowledge has been useful for designing urban habitat gardens where the emphasis is usually on achieving high species diversity and abundance (Frankie et al. 2009b; Jaime et al. 2009).

Knowing basic relationships can also extend into agricultural areas, where we have used them in northern and 
southern California studies to attract native bees to crop flowers (Frankie et al., in press). We have used this knowledge for constructing native bee habitat gardens in hedgerow plantings where we first begin by overstocking the rows with a wide variety of plants known to attract a generally wide diversity of bees. After a year or more of monitoring, we select plants that attract bees that are also visiting and pollinating crop flowers and focus on installing these plants, and at the same time reducing plant types that were not supporting bees that pollinate crop flowers. Selecting plants to be used for target bee species does not involve determining origins of the plants.

All of the $7500+$ bee-flower collection records from this survey will soon be available for examination and further study at the Essig Museum of Entomology at the University of California, Berkeley. These individual, bar-coded bee records could be useful as baseline information for climate change research in the future as they were compiled from 2005 $20 I I$, just as the current drought conditions were starting to be felt. Bee numbers have been declining since 2010 all over the state, but especially in southern California.

\section{ACKNOWLEDGEMENTS}

We thank the University of California, the California Agricultural Experiment Station, and the Contra Costa County Fish and Wildlife Committee for their continual support. We also thank Sara Leon Guerrero and Sara Witt for their help with collections and data compilations. Finally, we thank Kavya Niranjan and Adele Wallrich as well as other UC Berkeley undergraduate students who aided with fieldwork and specimen curation over the years. Kate Frey kindly read an early draft of this manuscript.

\section{APPENDICES}

Additional supporting information may be found in the online version of this article:

APPENDIX I. List of 229 bee species and the flowers they visit

\section{REFERENCES}

Atkins J, Atkins, B (2016) The Business of Bees, An integrated Approach to Bee Decline and Corporate Responsibility. Greenleaf Publishing, Sheffield, UK.

Baldock KC, Goddard MA, Hicks DM, Kunin WE, Mitschunas N, Osgathorpe LM, Potts SG, Robertson KM, Scott AV, Stone GN, Vaughan IP, Memmott J (20I5) Where is the UK's pollinator diversity? The importance of urban areas for flower-visiting insects.

Banaszak-Cibicka W, Zmihorski M (2012) Wild bees along an urban gradient: Winners and losers. Journal of Insect Conservation I6:33I-343.

Cane JH, Tepedino VJ (20II) Causes and extent of declines among native North America invertebrate pollinators: Detection, evidence, and consequences. Conservation Ecology 5:1-6.

Embry P (2018) Our Native Bees. Island Press.

Frankie GW, Thorp RW, Schindler M, Hernandez J, Ertter B, Rizzardi, M (2005) Ecological Patterns of Bees and Their Host Ornamental Flowers in Two Northern California Cities. Journal of the Kansas Entomological Society 78:227-246.

Frankie GW, Thorp RW, Hernandez J, Rizzardi M, Ertter B, Pawelek J, Witt SL, Schindler M, Coville R, Wojcik VA (2009a)
Native bees are a rich natural resource in urban California gardens. California Agriculture 63:I13-I20.

Frankie GW, Thorp, RW, Pawelek JC, Hernandez J, Coville R (2009b) Urban bee diversity in a small residential garden in northern California. Journal of Hymenoptera Research I8:368379.

Frankie GW, Vinson SB, Rizzardi M, Griswold TL, Coville RE, Grayum MH, Pawelek JC (2013) Relationships of Bees to Host Ornamental and Weedy Flowers in Urban Northwest Guanacaste Province, Costa Rica. Journal of the Kansas Entomological Society 86:325-35I.

Frankie GW, Thorp RW, Coville RE, Ertter B (2014) California Bees \& Blooms. Heyday.

Frankie GW, Coville RE, Pawelek JC, Jadallah CC, Vinson SB, Martinez LES (2018) Bee-flower-people relationships, field biologists, and conservation in northwest urban Costa Rica and beyond. Zoosymposia. http://www.mapress.com/j/zs/.

Garibaldi LA, Steffan-Dewenter I, Winfree R, Aizen MA, Bommarco R, Cunningham SA, Kremen C, Carvalheiro LG, Harder LD, Afik O, Bartomeus I, Benjamin F, Boreux V, Cariveau D, Chacoff NP, Dudenhöffer JH, Freitas BM, Ghazoul J, Greenleaf S, Hipólito J, Holzchuh A, Howlett B, Isaacs R, Javorek SK, Kennedy CM, Krewenka K, Krishnan S, Mandelik Y, Mayfield MM, Motzke I, Munyuli T, Nault BA, Otieno M, Petersen J, Pisanty G, Potts SG, Rader R, Ricketts TH, Rundölf M, Seymour CL, Schüepp C, Szentgyörgyi H, Taki H, Tscharntke T, Vergara CH, Viana BF, Wanger TC, Westphal C, Williams N, Klein AM (2013) Wild pollinators enhance fruit set of crops regardless of honey bee abundnance. Sciencexpress I0:I226.

Goddard MA, Dougill AJ, Benton TG (2010) Scaling up from gardens: biodiversity conservation in urban environments. Trends in Ecology and Evolution 25:90-98.

Hall DM, Camilo GR, Tonietto RK, Ollerton J, Ahrne K, Arduser M, Ascher JS, Baldock KCR, Fowler R, Frankie GW, Goulson D, Funnarsson B, Hanley ME, Jackson JI, Langellotto G, Lowenstein D, Mino, ES, Philpott SM, Potts SG, Sirohi MH, Spevak EM, Stone GN, Threlfall CG (2016) The city as a refuge for insect pollinators. Conservation Biology 31: 24-29.

Hanson T (2018) Buzz, The Nature and Necessity of Bees. Basic Books, New York.

Harrison T, Winfree R (2015) Urban drivers of plant-pollinator interactions. Functional Ecology 29:879-888.

Harrison T, Gibbs J, Winfree R (2017a) Anthropogenic landscapes support fewer rare bee species. Landscape Ecology https://doi.org/10.1007/sI0980-017-0592-x

Harrison T, Gibbs J, Winfree R (2017b) Forest bees are replaced in agricultural and urban landscapes by native species with different phonologies and life-history traits. Global Change Biology 24:287296.

Hernandez JJL, Frankie GW, Thorp RW (2009) Ecology of Urban Bees: A Review of Current Knowledge and Directions for Future Study. Cities and the Environment 2:I-I5.

Kleijn D, Winfree R, Bartomeus I, Carvalheiro LG, Henry M, Isaacs R, Klein A, Kremen C, M'Gonigle LK, Rader R, Ricketts TH Williams NM, Adamson NL, Ascher JS, Báldi A, Batáry P, Benjamin F, Biesmeijer JC, Blitzer EJ, Bommarco R, Brand MR, Bretagnolle V, Button L, Cariveau DP, Chifflet R, Colville JF, Danforth BN, Elle E, Garratt MPD, Herzog F, Hollzschuh A, Howlett BG, Juaker F, Jha S, Knop E, Krewenka KM, Féon VL, Mandelik Y, May EA, Park MG, Pisanty G, Reemer M, Riedinger V, Rollin O, Rundlöf M, Sardiñas H, Scheper J, Sciligo AR, Smith HG, Steffan-Dewenter I, Thorp R, Tscharntke T, Verhulst J, 
Viana BF, Vaissière BE, Veldtman R, Ward KL, Westphal C, Potts SG (2015) Delivery of crop pollination services is an insufficient argument for wild pollinator conservation. Nature Communications 6, 74I4.

Koh I, Lonsdorf EV, Williams NM, Brittain C, Isaacs R, Gibbs J, Ricketts TH (2016) Modeling the status, trends, and impacts of wild bee abundance in the United States. Proceedings of the National Academy of Sciences I 13:140-I45.

Losey JE,Vaughan M (2006) The economic value of ecological services provided by insects. BioSciences. 56:3 I I-323.

Mader E, Sheperd M, Vaughan M, Black H, LeBuhn G (2011) Attracting Native Pollinators. The Xerces Society, Storey Publishing, MA.

Mattheson KC, Ascher JS, Langelloto GA (2008) Bee richness and abundance in New York city urban gardens. Annals of the Entomological Society of America IOI: I40-I50.

Mattheson KC, Langelloto GA (20II) Small scale additions of native plants fail to increase beneficial insect richness in urban gardens. Insect Conservation Diversity 4:89-98.

Moisset BB, Buchmann S (20II) Bee Basics: An Introduction to Our Native Bees. [Online] URL: https://efotg.sc.egov.usda.gov/ references/public/SC/Bee_Basics_North_American_Bee_ID.pdf (accessed July 2017).

NAS (2007) Status of Pollinators in North America National Research Council of the National Academics. National Academics Press, Washington, D.C.

Owen J (199I) The ecology of a garden: the first fifteen years. Cambridge University Press.

O’Toole C (20I3) Bees, A Natural History. Firefly Books, New York.
Pardee GL, Philpott SM (2014) Native plants are the bee's knees: local and landscape predictors of bee richness and abundance in backyard gardens. Urban Ecosystems 17:64I-659.

Pawelek JC, Frankie GW, Thorp RW, Przybylski M (2009) Modification of a community garden to attract native bee pollinators in urban San Luis Obispo, California. Cities and the Environment 2:I.

Potts SG, Biesmeijer JC, Kremen C, Neumann P, Schweiger O, Kunin WE (2010) Global pollinator declines: Trends, impacts and drivers. Trends in Ecology and Evolution 25:345-353.

Salisbury A, Armitage J, Bostock H, Perry J, Tatchell M, Thompson K (20I5) EDITOR'S CHOICE: Enhancing gardens as habitats for flower-visiting aerial insects (pollinators): should we plant native or exotic species? Journal of Applied Ecology 52:1 I56II 64 .

Schlaepfer MA, Sax DF, Olden JD (20II) The potential conservation value of non-native species. Conservation Biology 25:428-437.

Tepedino VJ, Bradley BA, Griswold TL (2008) Might flowers of invasive plants increase native bee carrying capacity? Intimations from Capitol Reef National Park, Utah. Natural Areas Journal 28:44-50.

Williams NM, Cariveau D, Winfree R, Kremen C (20II) Bees in disturbed habitats use, but do not prefer, alien plants. Basic and Applied Ecology I2:332-34I.

Williams P, Thorp R, Richardson L, Colla S (20I4). Bumble Bees of North America. Princeton University Press, New Jersey.

Wilson JS, Carril OM (2016) The bees in your backyard. Princeton University Press, Princeton, New Jersey. 